\title{
UNDERSTANDING INFLATION: IMPLICATIONS FOR MONETARY POLICY
}

\author{
Stephen G. Cecchetti \\ Erica L. Groshen \\ Working Paper 7482 \\ http://www.nber.org/papers/w7482
NATIONAL BUREAU OF ECONOMIC RESEARCH 1050 Massachusetts Avenue
Cambridge, MA 02138
January 2000

This paper was written as an invited lecture at the Twelfth World Congress of the International Economic Association, Buenos Aires, Argentina, August 23-27, 1999. We are grateful to Jacques Dreze for asking us to organize our thoughts on this topic, to Roisin O'Sullivan and Palle Andersen for comments, to Valerie LaPorte for editorial assistance and to Nathaniel Baum-Snow for research assistance. The views expressed herein are those of the authors and not necessarily those of the National Bureau of Economic Research.

(C) 2000 by Stephen G. Cecchetti and Erica L. Groshen. All rights reserved. Short sections of text, not to exceed two paragraphs, may be quoted without explicit permission provided that full credit, including $\mathbb{C}$ notice, is given to the source. 
Understanding Inflation: Implications for Monetary Policy

Stephen G. Cecchetti and Erica L. Groshen

NBER Working Paper No. 7482

January 2000

JEL No. E31, E58, J30

\begin{abstract}
$\underline{\text { ABSTRACT }}$
This paper discusses how optimal monetary policy is affected by differences in the combination of shocks an economy experiences and the rigidities it exhibits. Without both nominal rigidities and economic shocks, monetary policy would be irrelevant. Recognizing this, policymakers increasingly incorporate the understanding gained from new research on rigidities and shocks into both their policy actions and the design of monetary institutions. Specifically, shocks can be predominantly real, affecting relative prices, or primarily nominal, moving the general price level. They may also be big or small, frequent or rare. Similarly, some nominal rigidities are symmetrical, affecting both upward and downward movements equally, while others are asymmetrical, restricting decreases more than increases. After reviewing major trends in the conduct of monetary policy, we describe how the growing theoretical and empirical literature on shocks and rigidities informs three

crucial dimensions of monetary policymaking. First, we discuss why trimmed means provide the best measure of core inflation. Second, we outline how rigidities impede policymakers' ability to control inflation. And third, we describe how alternative shock/rigidity combinations create inflation's grease (whereby it improves economic efficiency by speeding adjustment) and sand effects (whereby it distorts price signals) with their contrasting implications for the optimal level of inflation. We conclude by considering some key implications for monetary policy.
\end{abstract}

Stephen G. Cecchetti

Department of Economics

Ohio State University

Columbus, Ohio 43210

and NBER

cecchetti.1@osu.edu
Erica L Groshen

Bank for International Settlements

Centralbahnplatz 2

$\mathrm{CH}-4002$ Basle

Switzerland

and Federal Reserve Bank of New York

erica.groshen@bis.org 


\section{INTRODUCTION}

If prices and wages were perfectly flexible, monetary policy would be irrelevant. But casual observation suggests both that nominal prices and wages are at least somewhat rigid and that monetary policy has real effects. Economists' understanding of the nature of these rigidities has improved in recent years. At the same time, policymakers have begun to incorporate economists' theoretical and empirical findings in their institutions and actions. This paper explores the ways in which our empirical understanding of nominal rigidities informs three key dimensions of the conduct of monetary policy: how we measure core inflation, how we control inflation, and how we choose inflation targets.

The overriding theme of our analysis is that an understanding of the nature of shocks and rigidities is crucial for the conduct of a sound monetary policy. Shocks and rigidities vary along a number of dimensions. Efficient inflation measurement, optimal inflation goals, and the effective execution of policy will all vary depending on these aspects of an economy's structure.

To be specific, shocks can be predominantly real, affecting relative prices, or primarily nominal, moving the general price level. They may also be big or small, and they may be frequent or rare. Different economies are susceptible to very different types of shocks. For example, a country like the United States or a region like the European Monetary Union primarily faces small background shocks. Alternatively, Australia, a country heavily dependent on its exports of raw materials, and Norway, an oil-producing country, are more prone to occasional large shocks.

Similarly, there are several key differences in rigidities. Some nominal rigidities are symmetrical, affecting movements both up and down, while others exhibit more stickiness downward. In addition, rigidities can vary in their degree. For example, if symmetric wage and price stickiness is a result of costly adjustment (menu costs), then economies that have recently experienced high inflation may have implemented price- and wage-change technologies that make individual changes less costly, result- 
ing in more frequent adjustments and a lower level of symmetric stickiness. Downward rigidity will also vary among countries, depending, for example, on wage-setting practices.

With this in mind, we begin our analysis by noting the diversity of approaches to the conduct of monetary policy around the world. Countries vary substantially in their choice of regime. Some target inflation explicitly, others target money, and still others attempt to fix their exchange rates. Not surprisingly, their macroeconomic circumstances and outcomes have varied dramatically as well. These divergences raise questions about how various types of nominal rigidity affect each aspect of monetary policy. In particular, what evidence do we have of the existence of specific rigidities, and what is the implication for the conduct of monetary policy?

The first monetary policy issue we address concerns the measurement of core, or trend, inflation. Rigidities cause inflation-induced price adjustments to occur asynchronously, an effect that introduces biases into the usual measures of price changes and lowers the signal-to-noise ratio in such measures. Recent research has advanced our understanding of these issues and offers some intriguing alternatives (such as medians and trimmed means) to the common average index.

Second, the nature and extent of rigidities create potentially variable lags in the monetary policy transmission mechanism, complicating the policymaker's job. The execution of policy requires forecasts of the variables of interest - normally output and inflation - plus a quantitative estimate of the impact of policy changes. In addition to obscuring the level of trend inflation, nominal rigidities make price and wage adjustments dependent on the actual pattern of shocks hitting the economy, introducing considerable uncertainty into inflation forecasts, and complicating the measurement of the impact of policy substantially. Recent research illuminates the nature of this challenge and suggests how we might formulate policy in the face of this uncertainty.

Third, the nature of shocks and rigidities affects the level of inflation that mone- 
tary policymakers should target. Our paper looks at two combinations of shocks and rigidities and their contrasting implications for optimal targets. Symmetric rigidities with nominal shocks imply that optimal inflation should be close to zero. Downward rigidities with real shocks imply that zero inflation is too low a target.

We conclude our analysis by considering some implications of recent theoretical and empirical research on wage and price rigidity for the implementation of monetary policy. First, we suggest ways in which the inflation trend can be more accurately measured, and second, we address the question of how best to select an inflation target.

\section{CONDUCT OF MONETARY POLICY}

The decade of the 1990s has seen a convergence in the goals and methods used for the conduct of monetary policy around the world. A number of forces have driven this development. First, during the high inflation of the 1970s and 1980s, many countries saw prices rise well in excess of 50 percent per year for extended periods. ${ }^{1}$ This experience led to a clear consensus that even moderate levels of inflation damage real growth and that low inflation must therefore be a primary objective of monetary policy. Casual observation suggests that low-inflation countries experience higher growth rates, and so there are strong incentives to devise ways in which to keep inflation low. ${ }^{2}$

Second, evidence indicates that in most countries, short-run money demand functions are unstable and so meaningful measures of money, such as M3, are very difficult to control. As a result, monetary targeting alone is no longer viewed as a viable strategy for stabilizing prices. Finally, excessive exchange rate volatility is seen as damaging. The discussion about the appropriate exchange rate regime is clearly on-

\footnotetext{
${ }^{1}$ Examples include Bolivia, Israel, and Argentina.

${ }^{2}$ The literature on the connection between inflation and growth is large and growing, with less than robust results. Andrés and Hernando (1999) is a recent example.
} 
going, but a shrinking cohort of countries organize their policy framework with the goal of reducing or eliminating fluctuations in the value of their currency relative to that of some anchor country. Since these anchor countries typically have low inflation, this strategy calls for maintaining similar low rates.

As consensus has grown on these issues, many countries have redesigned their central banks and, for the most part, achieved remarkable reductions in inflation. ${ }^{3}$ A survey of 77 countries reported in Morandé and Schmidt-Hebbel (1999) divides countries into three groups on the basis of their monetary policy regime: exchange rate targeting, monetary targeting, or inflation targeting. The recent trend favors explicit or implicit inflation targeting. At least ten countries or central banks now set explicit inflation targets that clearly dominate any other targets or objectives. These countries are New Zealand, which in 1988 became the first industrialized country to adopt an explicit "hard" inflation target; Canada, Chile, and Israel, which adopted inflation targeting in 1991; the United Kingdom, which moved to explicit inflation targets in 1992; and Australia and Sweden, which changed their policy frameworks in 1993; the Czech Republic and Spain which adopted targets in 1994 and 1995, respectively; and the European Central Bank, which announced a target in 1999. Morandé and Schmidt-Hebbel (1999) list a total of 45 countries that, over the past decade, have adopted some form of inflation target: 12 industrialized, 12 transitional and 21 developing. ${ }^{4}$ Similarly, many other countries have changed their monetary regimes to target monetary aggregates or exchange rates with the goal of creating a credible low inflation policy. ${ }^{5}$

\footnotetext{
${ }^{3}$ Mishkin (1999) provides a discussion of the recent international experience of various monetary regimes.

${ }^{4}$ In their Table 1, Morandé and Schmidt-Hebbel (1999) also identify 34 countries that target primarily money and 36 that target exchange rates.

${ }^{5}$ The political economy of monetary policy and the importance of credibility have been widely studied. The research in this area has focused on the importance of a structure in which the central bank is independent of the elected officials in the government. See, for example, Alesina and Summers (1993). With independence of operation comes the need for central banks to be accountable for their performance, usually relative to an inflation objective set by statute or agreement with other branches of government.
} 
Regardless of the specific target a country chooses for implementing monetary policy, central banks face a number of practical difficulties in maintaining low levels of inflation. Inflation-targeting countries must specify an index to target, set a level for the target, decide whether to state the target as a band (for example, between zero and two percent) or as a point, and choose the number of quarters or years over which the target will be averaged. Similar choices must be made by countries that target money or exchange rates. These practical decisions are best based on a solid theoretical and empirical understanding of the processes underlying inflation. Fortunately, in recent years, economic research has shed considerable light on these processes. The next three sections of this paper survey what we now know about core inflation measurement, inflation control, and the choice of an optimal long-term inflation level.

\section{CORE INFLATION MEASUREMENT}

Before policymakers can hope to control inflation, they must measure it; preferably on a timely basis. ${ }^{6}$ This is a difficult task that has attracted substantial attention among both academic and central bank economists. ${ }^{7}$ One of the primary difficulties associated with the measurement of inflation is the presence of considerable amounts of transitory noise. ${ }^{8}$ That is, monthly or quarterly inflation readings can differ significantly from the longer term trend in inflation. A few numbers provide

\footnotetext{
${ }^{6}$ Throughout this section, we assume that measurement of core inflation is a statistical problem associated with the estimation of a long-run trend movements in prices. Other conceptions are surely possible, all of which would be based on structural economic models. For example, Quah and Vahey (1995), motivated by the concept of a long-run vertical Phillips curve, define core inflation to be the component of measured inflation that has no impact on real output in the long run. We shy away from such definitions, as they are highly parametric and therefore unlikely to provide timely evidence on structural breaks in the inflation process.

${ }^{7}$ The literature on core inflation, now vast, began with Eckstein (1981). Wynne (1999) provides a recent survey.

${ }^{8} \mathrm{~A}$ second difficulty is the presence of bias in price indexes. For recent work in this area, see the survey in Shapiro and Wilcox (1996).
} 
some perspective. Over the past fifteen years, the standard deviation of (annualized) monthly changes in the U.S. Consumer Price Index has been 2.2 percentage points. Meanwhile, the 12-month changes have had a standard deviation that is half that value, or 1.1 percent; and the 36-month moving average has had a standard deviation of only 0.8. Clearly the monthly changes in consumer prices provide only limited information about the trend.

The experience of the first half of 1999 provides an excellent example of how noisy and confusing monthly CPI movements can be. The monthly readings varied between zero (there was no change from April to May) and nearly 9 percent (from March to April) at an annual rate. All the while, the trend was very likely somewhere between 2 and 3 percent per year. Although this example is surely extreme, it points out a serious practical problem. How far do monthly or quarterly aggregate price indexes have to move away from the perceived trend in inflation before policymakers change their view of the trend? Put another way, when and how should monetary policymakers respond to what look initially like short-term inflation changes?

To address these issues, we first need to identify the sources of this noise. Once we have this information, we can start to find ways of reducing the noise in our measured indexes. Experience suggests that transitory moves in price indexes are often attributable to clearly discernible events. We can distinguish among three different types of transitory CPI noise. These are summarized in Table 1, and we now describe them further.

First, inflationary price changes are not uniform. That is, different prices adjust at different times because nominal price adjustment is costly and adjustment costs differ across products. Prices which are costly to change (such as rents) will be more rigid, that is they will change less often, but by larger increments when they do. This variation leads to divergent inflation measures across products and time even if the trend is unchanged.

Second, relative price changes (reflecting real shocks) can temporarily affect mea- 
Table 1: Three Sources of Noise in Inflation Measurement

\begin{tabular}{|l|l|l|l|}
\hline $\begin{array}{l}\text { Asynchronous } \\
\text { price changes }\end{array}$ & $\begin{array}{l}\text { Shock } \\
\text { price movements }\end{array}$ & $\begin{array}{l}\text { Rymmetric wage/ } \\
\text { price rigidity }\end{array}$ & $\begin{array}{l}\text { Flexible price sectors } \\
\text { adjust first, rigid } \\
\text { sectors lag }\end{array}$ \\
\hline $\begin{array}{l}\text { Incomplete } \\
\text { adjustment to } \\
\text { real shocks }\end{array}$ & $\begin{array}{l}\text { Real relative } \\
\text { wage/price } \\
\text { shock }\end{array}$ & $\begin{array}{l}\text { Symmetric wage/ } \\
\text { price rigidity }\end{array}$ & $\begin{array}{l}\text { Flexible price sectors } \\
\text { adjust first, rigid } \\
\text { sectors lag; or sectors } \\
\text { directly affected adjust } \\
\text { first, others lag }\end{array}$ \\
\hline $\begin{array}{l}\text { Flaws in } \\
\text { seasonal } \\
\text { adjustment }\end{array}$ & $\begin{array}{l}\text { Change in } \\
\text { timing of } \\
\text { seasonal }\end{array}$ & $\begin{array}{l}\text { Downward wage/ } \\
\text { price rigidity }\end{array}$ & $\begin{array}{l}\text { Positive changes occur } \\
\text { first, negative ones lag }\end{array}$ \\
\hline $\begin{array}{l}\text { timing rigidity } \\
\text { fymetric }\end{array}$ & $\begin{array}{l}\text { Seasonal adjustment } \\
\text { itself yields sectoral } \\
\text { changes that are } \\
\text { temporarily over- or } \\
\text { or understated }\end{array}$ \\
\hline
\end{tabular}

sures of inflation even if they are not associated with a nominal shock. Some sectors may be affected more rapidly than others because they are directly exposed, or because they have more flexible prices. In addition, if prices are rigid downwards, then upward price movements will occur before the compensating downward adjustments. Broad-based resource shocks, such as variation in petroleum prices, will have widely divergent effects on the prices of different consumer goods, and these do not all occur simultaneously. Exchange-rate shifts also affect prices differently; the prices of imported and import-competing goods are much more likely to change quickly than the prices of nontraded goods and services. Moreover, the size and timing of real shocks differ across sectors, leading to heterogeneous price changes.

Finally, because the CPI is measured on a monthly basis, inexact seasonal adjustment can also add noise to inflation measures. Firms with high costs of adjustment 
will limit the frequency with which they change prices. When these adjustments are coordinated among firms within a sector, they produce recurrent patterns. In order to reveal movements in the trend, statistical agencies use various adjustment techniques to remove normal seasonal fluctuations from the monthly numbers. However, these techniques are not foolproof. In particular, minor changes in the timing of price adjustments - say, a decision by apparel manufacturers to change the prices of summer clothes in February rather than March one year - can confound seasonal adjustment. In that case, February would record a jump in inflation matched by a corresponding drop in March.

These observations suggest that prices from different sectors of the economy will contain different amounts of information about inflation trends. There is considerable variation both in the importance of shocks and in the degree of nominal rigidity. Some industries are more prone to large relative price movements than others, and some product prices are easier to change. Measuring the inflation trend requires that we sort out the real shocks from the nominal ones on an economy-wide basis, taking account of these potentially large cross-sectional differences.

A common strategy used to estimate core inflation is to systematically remove certain components of the price indexes. In the United States, it is standard to remove food and energy prices, both of which appear substantially more volatile than prices of other goods and services. The rationale is that short-term movements in these prices stem from rapid adjustment to frequent real shocks that are often reversed, and so they contain substantially less information about the long-term trend.

Returning to the experience of early 1999, we can see the benefits of excluding food and energy prices when trying to gauge the inflation trend. The highest reading of the CPI excluding food and energy is again from March to April, but the increase is estimated at just $43 / 4$ percent (at an annual rate). The lowest reading is from January to February, and is slightly below 0.7 percent at an annual rate. By excluding food and energy, the range of inflation readings over this brief five-month period is 
reduced by more than one-half, from nearly 9 percent to just over 4 percent.

Still, the strategy of excluding food and energy relies on two arbitrary assumptions: that food and energy prices never contain information about the inflation trend, and that other prices always do. Neither of these assumptions is likely to be true. An alternative approach would be to look to economic theory for guidance on how we might construct measures of trend or core inflation. This strategy, adopted in a series of papers by Bryan and Cecchetti, ${ }^{9}$ is based on the observation that the economy is, roughly speaking, composed of two groups of price setters. The first have flexible prices in the sense that they set their prices every period in response to realized changes in the economy. Common examples include producers of fruits, vegetables, and motor fuel. The second group of price setters, by contrast, set prices infrequently, and face potentially high costs of readjustment. For example, we are thinking about those who set prices for housing rentals, restaurant meals or magazines at the newsstand. ${ }^{10}$ New Keynesian macroeconomic theory focuses on this second group in building models in which, as a result of sticky prices and menu costs, purely nominal disturbances have potentially long-lived real effects. The first group, the realization-based price setters, have the potential to create noise in standard price indexes. Because they can change their prices quickly and often, these firms have little reason to care about long-term trends in aggregate inflation. In sectors where prices are costly to change, price setters cannot correct mistakes quickly, and so the paths of their prices are much smoother. Prices set by these expectations-based price setters contain information about the trend that is not present in the flexible prices of the first group.

To give some indication of the relative volatility of different prices, we have computed some simple standard deviations from monthly component price indexes. Looking at the period since 1985, we find that the highest variation is in the prices of fuel

\footnotetext{
${ }^{9}$ See Bryan and Cecchetti (1994) and Bryan, Cecchetti, and Wiggins (1997).

${ }^{10}$ Cecchetti (1986) provides evidence of the rigidities in the price of one such good: magazines.
} 
oil (for home heating), motor fuel (for cars), and fruits and vegetables. The standard deviation of monthly changes in inflation in these commodities (measured at an annual rate) ranges from 23 percent for the food stuffs to 45 percent for fuel oil. This is between 10 and 20 times the standard deviation in the overall CPI. At the other end of the spectrum are "food away from home" (restaurant meals) and shelter (which largely measures housing rental costs, or the rental equivalent value of home ownership)-the only two significant components with less volatility than the overall CPI.

These observations have led to the development of a new set of price measures that combine existing price data differently. The logic, as described in Bryan and Cecchetti (1994), is straightforward. Each firm in the economy adjusts prices taking into account anticipated future developments. Following an initial adjustment, previously unanticipated shocks hit the economy. These real shocks create the desire for relative price adjustments. Only some firms experience shocks that are large enough to make immediate adjustment worthwhile. As a result, the observed change in the aggregate price level will depend on the shape of the distribution of the desired adjustments. In particular, if this distribution is skewed (as often seems to be the case in practice), then the aggregate price level will move up or down temporarily. Once every firm adjusts its prices, this transitory movement in the aggregate index disappears. ${ }^{11}$

The proposed solution to the problem of noise created by infrequent and asynchronous adjustment (in the absence of downward price rigidity) is to use alternative statistical procedures for combining the disaggregated inflation information. The standard methodology for computing the aggregate CPI is to construct a weighted average of price data, in which the weights are based on expenditure surveys. But the sample mean is only one potential estimate of the central tendency of a distribution.

\footnotetext{
${ }^{11}$ If there is significant downward rigidity, and a significant number of firms would wish to lower their prices, the problem is even more severe. The process of complete adjustment can be very slow, and in the meantime the aggregate price level can move significantly, making real shocks look like nominal ones.
} 
An alternative is to use the (weighted) median of the component inflation data, as well as measures called trimmed means. ${ }^{12}$ Trimmed means are a generalization of the concept of a median. A sample of data is first ordered, as it is in the construction of the median, and then some percentage of the highest and lowest observations are eliminated while the remainder are averaged. For example, if one has 100 sample data points, then the computation of a 15 percent trimmed mean involves averaging the 70 observations in the center of the distribution. ${ }^{13}$

Trimmed means are a natural solution to the difficulties created by nominal rigidities. In contrast to the average CPI excluding food and energy (which assumes that all noise comes from two sectors), the trimmed mean assumes that any extreme change is probably noise, no matter what sector it comes from. That is, the trimmed mean focuses on the center of the distribution to tell us what the trend is doing. As noted just above, when firms face costs of price adjustment, and the desired price changes are skewed, then the aggregate price index will contain transitory movements reflecting the fact that only price setters who wish to make large moves will find it worth paying the cost. Substitution of a trimmed mean or the median for the sample average will reduce this source of noise and improve the signal policymakers need.

To see the difference this can make, we return to a comparison of the median CPI with the all-items CPI and the CPI excluding food and energy. Looking at the median in the first few months of 1999, we see that the lowest reading is 1.3 percent from February to March, and the highest reading is 3.6 percent, from March to April, both at an annual rate. Thus, the range for the all-items CPI is nearly 9 percent, for the CPI excluding food and energy, it is 4 percent, and for the median it is 2.3

\footnotetext{
${ }^{12}$ Wynne (1999) discusses several other alternatives, including weighting individual prices by the inverse of their estimated variance. A procedure first suggested by Dow (1994).

${ }^{13}$ Bryan, Cecchetti, and Wiggins (1997) discuss a statistical rationale for computing trimmed means. They note that a trimmed mean can be a more efficient, reduced-variance estimator of the true mean when the underlying distribution of the data has fat tails. Inflation data generally exhibit very high kurtosis relative to the normal distribution, suggesting that trimmed means can provide improvements.
} 
percent. Moreover, the standard deviation in monthly inflation for the past fifteen years is 2.1 percent for the all-item CPI, 1.4 percent for the CPI excluding food and energy, and 1.3 percent for the median (again, all values are at an annual rate). We will simply note that it is possible to improve on this last measure by choosing the trimmed mean that minimizes monthly variation.

An inflation-targeting regime needs both an appropriate, transparent target and timely information about the trend in that measure. The research cited above suggests that trimmed means provide superior timely measures of trend inflation. However, the public is unfamiliar with this measure. Thus, adoption of a trimmed mean might not offer the transparency desirable in an inflation goal. If so, how can these findings be incorporated into an inflation targeting regime? We offer two possibilities. The first is to have the measure produced, announced and explained by a statistical agency independent of the central bank. This role for a disinterested party should alleviate most concerns and increase understanding of the rationale for the unfamiliar measure. Alternatively, a central bank could maintain an average CPI target, but rely on the trimmed mean as the best short-run monitoring device for tracking trends. Since the advantage of the trimmed mean lies in its lower sensitivity to noise, while preserving the trend (as captured in long-run averages), this tack is theoretically sound. In either case, transparency and sound monetary policy both dictate the need for an extensive study of the dynamic and long-run relationship between the trimmed mean and average CPI in their country. Then, the central bank must be prepared to explain policy decisions in light of both measures.

Many central banks now compute a number of alternative estimates of core inflation, including medians and trimmed means. Álvarez and de los Llanos Matea (1999) cite numerous examples. We note here several interesting empirical regularities. First, for the dozen or so countries for which we have seen data, the median significantly reduces high-frequency noise. Second, we note that for countries other than the United States, the median appears to be systematically below the mean. The reason for 
this second finding is that, outside the United States, cross-section distributions of long-run price changes are positively skewed. This could suggest greater downward rigidities in those countries, but fuller explanation of the finding will require further research.

\section{INFLATION CONTROL}

It is generally agreed that all central banks should strive to reduce inflation and keep it at low levels. While the measurement of inflation poses substantial challenges, these seem minor in comparison with the difficulties of controlling inflation.

Inflation control can be thought of as a fairly technical problem in which the policymaker uses an instrument such as an interest rate to meet an inflation (or output growth) objective. ${ }^{14}$ To carry out such a task, the policymakers must have a substantial amount of information. Most importantly the policymaker needs to know what will happen to the objective (inflation) in the absence of any policy action, as well as what the impact of any particular action on the objective will be. Thus, inflation control requires forecasts of inflation and estimates of the response of inflation to changes in interest rates. Neither of these is straightforward to obtain.

Forecasting inflation is a daunting task. For example, over the past decade, the standard deviation of forecast errors in professional forecasters' predictions of U.S. inflation one year ahead has been about 1 full percentage point, implying a 90 percent confidence band of about 3 percentage points. Over this same period, inflation has averaged only about 3 percent. Nothing seems to forecast inflation very well, except inflation's own history. ${ }^{15}$ Indeed, the relationship between price inflation and any potential indicator-such as wages, unemployment, or commodity prices-is very unstable. Theory provides us with a reason for the difficulty of forecasting: When

\footnotetext{
${ }^{14}$ Cecchetti (1998) discusses this problem in detail, noting that the objective is usually expressed in terms of a trade-off between output and inflation variability.

${ }^{15}$ See Cecchetti (1995).
} 
monetary policy regimes change, the relationship among various quantities in the economy shift as well, rendering prior statistical regularities unreliable.

From here the problem only gets worse. Not only is it difficult to forecast inflation, but our ability to predict the effect of monetary policy actions on inflation (and output) is very limited. A number of researchers have estimated the response of prices to interest rate movements in many countries. The first difficulty is in getting the estimates to display the proper sign. Most of us have a fairly firm belief that increases in interest rates are consistent with monetary contractions and should eventually drive inflation down. Unfortunately, it is more difficult than one would think to obtain this empirical result in standard models. ${ }^{16}$ Then, beyond the difficulty of obtaining the proper sign, lie the issues of precision and statistical significance. For example, using a simple four-variable model (encompassing output, aggregate prices, commodity prices, and the federal funds rate), one can estimate that a 100 basis point increase in interest rates will drive inflation down by about one-half of one percentage point after three years. But two standard deviation bands on this estimate go from approximately plus 1 percent to minus $13 / 4$ percent. $^{17}$

Why is it so difficult to estimate the effects of monetary policy actions? The answer is both that the economy responds to different shocks in different ways, and that the economy's response depends on history, so the same shock will prompt different reactions at different times. Textbook discussions treat the transmission mechanism as invariant to the path by which the economy has arrived at its current state. This is surely not true. Consider for a minute the implications of costly price adjustment. A large monetary shock will lead all firms to adjust and thus could result in smaller real effects than a small nominal shock that causes incomplete adjustment. The path of such shocks matters as well. Standard tools for estimating the economy's response to monetary policy actions are ill-suited to capturing the nonlinear responses that

\footnotetext{
${ }^{16}$ See Sims (1992) for a discussion of the problem that has come to be known as the price puzzle.

${ }^{17}$ These estimates are derived from Cecchetti (1996).
} 
theoretical models suggest should be pervasive. As the literature makes clear, linear approximations do not work well. Rigidities obscure both trend inflation and the impact of policy actions from the policymaker's view.

Policy is made every day, and so despairing over our lack of knowledge and the inadequacies of our models is pointless. Instead, the most productive course is to take seriously the need to make policy in an uncertain and unstable environment. The imprecision of our knowledge must be built into the fundamentals of our policymaking procedures.

\section{THE OPTIMAL RATE OF INFLATION}

Higher prices or faster inflation can diminish involuntary, disequilibrium unemployment.... The economy is in perpetual...disequilibrium even when it has settled into a stochastic macro-equilibrium.... When wages are rigid downward] price inflation...is a neutral method of making arbitrary money wage paths conform to the realities of productivity growth.

James Tobin, 'Inflation and Unemployment,' American Economic Association Presidential Address (1972).

[Higher, more variable inflation causes: a] reduction in the capacity of the price system to guide economic activity; distortions in relative prices because of the introduction of greater friction, as it were, in all markets; and very likely, a higher recorded rate of unemployment.

Milton Friedman, 'Inflation and Unemployment,' Nobel Lecture (1977).

Who is right? Widespread reductions in core inflation and the growing use of explicit or implicit inflation targets by central banks make this question particularly relevant. Is the most economically efficient level of price changes zero, as Friedman suggests, or something greater than zero, as Tobin implies? The answer depends both on the structural rigidities in the economy and on the type of shocks the economy 
faces. But while the effectiveness of monetary policy depends on the nature of nominal rigidities, and the task of the policymaker is to respond to external shocks, not all rigidities and not all shocks are created the same. Differences in the types of shocks to which a country is prone and the types of rigidities built into that country's wageand price-setting institutions will influence the optimal low-inflation goal.

Both the resolution of the controversy between Friedman and Tobin and the implications of this controversy for the choice of an optimal inflation target depend on the extent to which shocks are real or nominal, predominantly big or small; and the degree to which prices and wages are more rigid downward than up, and more or less sticky. A substantial amount of research has been devoted to these issues. ${ }^{18}$ Tobin's argument has been called the grease effect: a certain amount of inflation benefits economic performance in labor and product markets by allowing greater wage and price flexibility in the face of presumed downward rigidities. Maintaining the metaphor of the economy as a geared machine, we use the term "sand" to refer to Friedman's characterization of the affects of inflation: in this view, inflation interferes with the transmission of price signals, disrupting the smooth operation of the economy. We now turn to a discussion of each of these effects, which we summarize in Table 2.

\subsection{How Inflation Impairs Economic Efficiency: Sand}

The case for an optimal inflation level of zero (or lower) is based on the belief that the grease effects of inflation are small while the sand effects are big. In a world where wage and price rigidities cause asynchronous adjustment to shocks, inflation results in inefficient idiosyncratic price or wage adjustments and relative price distortions. This

\footnotetext{
${ }^{18}$ The bulk of this work centers on the labor market, as this is presumed to be the source of some of the most important nominal rigidities in the economy. Researchers tend to focus on wages for a number of reasons. First, labor accounts for two-thirds of production costs. Second, casual observation suggests that nominal wages are stickier than goods prices. Finally, wage data are more readily available than price data, making analysis easier.
} 
Table 2: Comparisons of Inflation's Grease and Sand Effects in the Labor Market

\begin{tabular}{|l|l|l|}
\hline & Sand & Grease \\
\hline Rigidities & $\begin{array}{l}\text { Symmetric: menu costs; } \\
\text { forecast disagreement } \\
\text { (uncertainty);timing } \\
\text { rigidities }\end{array}$ & $\begin{array}{l}\text { Asymmetric: downward } \\
\text { nominal rigidity } \\
\text { (money illusion, } \\
\text { nominal contracts, } \\
\text { fairness) }\end{array}$ \\
\hline Shocks & $\begin{array}{l}\text { Nominal, aggregate price } \\
\text { movements }\end{array}$ & $\begin{array}{l}\text { Real relative } \\
\text { wage/price shocks }\end{array}$ \\
\hline $\begin{array}{l}\text { Inflation's } \\
\text { welfare effects }\end{array}$ & $\begin{array}{l}\text { Disruptive-distorts relative } \\
\text { wages and prices, } \\
\text { misdirecting resources }\end{array}$ & $\begin{array}{l}\text { Beneficial-speeds wage } \\
\text { and price adjustments, } \\
\text { redirecting resources quickly }\end{array}$ \\
\hline $\begin{array}{l}\text { Limits on } \\
\text { welfare effects }\end{array}$ & None or cost of indexation & Size of real shocks \\
\hline $\begin{array}{l}\text { Price or wage } \\
\text { differentials affected }\end{array}$ & $\begin{array}{l}\text { Intra-market (within } \\
\text { products/skill-groups, } \\
\text { across companies) }\end{array}$ & $\begin{array}{l}\text { Inter-market across } \\
\text { products, inputs or } \\
\text { skill groups) }\end{array}$ \\
\hline
\end{tabular}


is the Friedman sand. ${ }^{19}$ The rigidities involved are symmetrical in that the costs of equal-sized upward or downward movements (in response to a change in the aggregate price level) are the same.

There are several reasons why firms might adjust differently to the same nominal shock, causing relative prices to vary. These include forecast disagreement, due to uncertainty; ${ }^{20}$ menu costs that result in episodic rather than continuous adjustment, (such as negotiating, advertising, and design costs) ${ }^{21}$ factors that make it difficult for consumers to comparison-shop (such as hard-to-gauge quality differences) $;{ }^{22}$ and contractual obligations such as collective bargaining agreements or leases. Asynchronous adjustment means that aggregate price movements are not transmitted instantaneously or uniformly, so market participants confuse adjustment lags or errors with real shocks. This misunderstanding has two effects. First, and most obviously, pricing errors result in resource misallocations. The second effect arises because people anticipate that resource misallocations will occur. The potential for arbitrary relative price movements creates risk that will lead firms to purchase insurance of various forms. For example, a firm may choose to build a smaller factory in order to guard against the possibility of variable profit streams. There is evidence that higher levels of inflation are associated with increases in this type of risk. ${ }^{23}$

We can conclude that asynchronous price and wage adjustment in the presence of inflation creates two complementary problems. First, it makes it difficult for policymakers to measure inflation accurately and expeditiously; second, it misleads economic agents. In the labor market, unintended wage changes alter firms' wages rel-

\footnotetext{
${ }^{19}$ Friedman has also argued that since the marginal producing cost of money is (nearly) zero, the social welfare maximizing level of real balances sets the nominal interest rate to zero. Optimal inflation is then minus the equilibrium real rate of interest. In our view, such a target would be extremely dangerous, since it dramatically increases the probability that policy errors force the real interest rate up unintentionally, since nominal interest rates will not be able to fall. For a further discussion on this point, see Cecchetti (1998b).

${ }^{20}$ See Friedman (1977).

${ }^{21}$ See Sheshinski and Weiss (1977).

${ }^{22}$ Stigler and Kindahl (1970) and Reinsdorf (1994).

${ }^{23}$ See Vining and Elwertowski (1976) and Huizinga (1993).
} 
ative to the market and can produce unnecessary layoffs, workforce dissatisfaction, or resignations. These wage changes can also impose additional costs by compelling firms to improve information or increase the frequency of adjustments.

The conclusion at this point is clear. If all shocks were nominal and rigidities were symmetrical, then the optimal level of inflation would be zero. In this environment, any positive level of inflation would disrupt price signals, and the higher the inflation the worse the disruptions. These costs could be mitigated by indexing or by policies aimed at improving forecasts; but these solutions themselves would redirect resources from more productive uses. Deflation would have identical effects, leading us to conclude that price stability would be most efficient. ${ }^{24}$

\subsection{How Inflation Overcomes Rigidities: Grease}

If shocks are predominantly real, creating a desire for firms and workers to adjust relative prices and wages, and nominal wages and prices are more rigid downward than upward, then the conclusion changes dramatically. In this case, prices, and therefore resource allocations, adjust slowly and inefficiently to shocks, and small amounts of inflation provide the means for the necessary adjustment by reducing real product prices or workers' real pay without a cut in the corresponding nominal prices or wages. This is the world of Tobin's grease effect.

There are a number of potential explanations for the presence of downward nominal rigidity. Chief among them is the view that social or bureaucratic norms discourage firms from either cutting the wages of good workers who face unfavorable market conditions or lowering the prices of goods with falling demand. This is the view originally expressed by Keynes, who thought that wage stickiness reflected social notions of fairness. Alternative explanations are based on the existence of long-term,

\footnotetext{
${ }^{24}$ Some economists contend that the tax distortions created by inflation reduce the level of output permanently, and from this concludes that the optimal level of inflation is negative. The relationship of inflation to public finance is beyond the narrow scope of our essay.
} 
nominal contracts (for example, for debt or wages) or money illusion (that is, workers resist cuts in their dollar earnings more than they resist equivalent rises in the prices of what they buy). ${ }^{25}$

The common view is that nominal prices are less downwardly rigid than nominal wages because products themselves are not influenced by social norms, nominal contracts or money illusion. However, the producers and distributors that set prices may well be subject to the same influences that affect firms setting wages since product sales represent income to them, just as wages do to workers. As a result, downward nominal rigidity may extend beyond the labor market and, to at least some degree, be present everywhere.

Clearly, in an environment where cutting nominal prices or wages is difficult, inflation can play an important role. Following a real shock, firms may be faced with a need to reduce relative prices or wages. If they are unable to do so, firms will eventually respond by reducing production and employment. Inflation relaxes downward wage and price rigidity because as other prices rise, firms can effectively lower real wages or prices without imposing nominal cuts. With this grease in place, wage and price signals travel more rapidly through the economy, reducing layoffs, providing more accurate incentives to workers choosing careers, and raising overall production while reducing its volatility. Thus, inflation reduces cyclical unemployment. An important corollary discussed in Tobin (1972) and further formalized by Akerlof, Dickens and Perry (1996), extends this reasoning to economies facing continual small "background" disturbances. In that case, inflation reduces steady-state unemployment.

Returning to the question at hand, we find again that the conclusion is clear. In an economy with downward wage and price rigidity and real shocks, the outputmaximizing (unemployment-minimizing) level of inflation will be somewhere above zero. It follows directly that the larger and more prevalent the shocks, the more

\footnotetext{
${ }^{25}$ See Haley (1990) for a review of the theories underlying downward wage rigidity.
} 
beneficial is inflation, and the higher the inflation rate should be to maximize output. By the same token, however, inflation beyond that needed to accommodate these adjustments adds no further benefits.

Surely, however, the conclusions reached by looking exclusively at either the sandinduced costs or the grease-generated benefits of inflation are unrealistic. We expect that the two effects can and do coexist. ${ }^{26}$ That is, economies can sustain both real and nominal shocks and have varying degrees of downward nominal rigidities. The optimal inflation goal depends on the balance between the nature of the shocks and rigidities in the economy. Thus, it is crucial that policymakers be aware of the empirical relevance of each effect to their current situation.

\subsection{Empirical Research on Rigidities and Inflation}

How can we detect the relative size of the grease and sand effects in order to help fix an inflation goal? The task seems difficult because both raise the variance of relative price changes. But, as shown in Table 2, two key differences are potentially observable. Increased price-change variability from sand's disruptions should be symmetrical and should occur even among the prices of otherwise identical goods. Thus, sand can be measured in studies of inflation's impact on intramarket (same-good) price changes. By contrast, the grease effect of inflation allows an economy to adjust to shocks that alter the relative wages (prices) of different skill groups (products). Hence, the grease effect is observed when inflation raises the dispersion of intermarket (that is, between skill-group or product) wage and price changes. In addition, its impact may be asymmetrical, as it facilitates downward movements more than upward ones.

\footnotetext{
${ }^{26}$ Groshen and Schweitzer (1996) demonstrate this formally in a model of the labor market.
} 


\section{Measures of Sand Effects}

The sand phenomenon has been studied in both the goods and the labor market. Sand studies gauge inflation's costs by measuring its tendency to raise intramarket prices unevenly.

Recent research on price adjustment variability uses narrow product micro data. Some studies consider price changes in a single class of goods, generally in low-inflation countries ${ }^{27}$ others have explored price changes for a wide variety of goods in highinflation environments. ${ }^{28}$ Examining price changes in the United States during high inflation years (1980-82), Reinsdorf (1994) finds that the variation in prices within a single product category rose when inflation fell unexpectedly. The variation of price changes across product categories, however, was positively correlated with inflation, and so it fell. More support for the sand hypothesis comes from the observed tendency of inflation to raise forecast price-change dispersion. ${ }^{29}$ On balance, these studies agree that price change and forecast variability rise with inflation, as predicted by the sand story.

Research using aggregate data on wages, however, seems to contradict the sand hypothesis. A number of studies find that the dispersion of wage changes fell as inflation rose in the late 1970 s and early 1980 s. $^{30}$ This seemingly contradictory result is attributed to the inflation-induced introduction of indexation, which makes wage changes more uniform across industries by tying them more closely to price inflation. In addition, since the datasets used in these studies leave investigators with a limited ability to control for business cycle variation in worker skill levels and workforce composition, the authors may be confusing intramarket sand effects with intermarket grease effects.

\footnotetext{
${ }^{27}$ See Cecchetti (1986) for magazines' cover prices.

${ }^{28}$ See Lach and Tsiddon (1992)

${ }^{29}$ See Ball and Cecchetti (1990).

${ }^{30}$ See the survey in Groshen and Schweitzer (1997) for discussion of these findings.
} 
The work of Groshen and Schweitzer $(1996,1999)$ reexamines this question using transaction-level data over a long time period. Their data set includes detailed information on occupation, and so allows for the type of controls that effectively replicate the comparability across goods (intramarket variability) sought in the product-price literature. They find that, over the full observed range of 1 to 14 percent, more inflation raises the variation of intramarket wage changes. Moreover, further increases in inflation appear to increase costs without bound.

\section{Measures of Grease Effects}

The original research investigating the existence of asymmetrical nominal rigidities examined aggregate time-series data. Testing whether aggregate real wages are procyclical (as implied by downward wage rigidity), investigators have concluded that wages (in the United States) are probably rigid downward. ${ }^{31}$ However, these results have been challenged by theorists who have provided models with identical predictions but fully flexible wages and prices. ${ }^{32}$

The response to this challenge has been to examine micro-level data and employ tests that are immune to the earlier criticisms. This research program provides more direct evidence in support of the hypothesis that wages are rigid downward. Some studies examine this question using household survey data and find evidence of substantial nominal wage cuts, which they take to contradict the existence of downward rigidity. But the data are plagued by various measurement errors that may drive the conclusions. ${ }^{33}$ More important, even if we take the evidence of these studies at face value, the existence of nominal wage cuts is neither necessary nor sufficient to demonstrate that wages are fully flexible, since we do not know how many wage cuts are needed to ensure efficient allocation of resources. Furthermore, the results obtained

\footnotetext{
${ }^{31}$ For a more detailed review of the results referred to in this section, see the survey in Groshen and Schweitzer (1997).

${ }^{32}$ The earliest example we know of is Lucas and Rapping (1969).

${ }^{33}$ Of particular concern is the fact that the data collection methods rely on individuals' memories and third-party reporting, creating large systematic errors in the measures of wage change.
} 
from looking at household survey data are contradicted by evidence obtained from interviewing employers and workers on the job. Employers report that their wagesetting policies have important downward rigidities built into them, and workers seem to agree. The studies all provide evidence that wages are downwardly rigid. Nominal wages are not cut unless there is explicit provision for flexible wages (such as through piece-rate or incentive systems) or the firm is under demonstrable financial distress.

More recent microeconometric studies, based on longitudinal datasets that allow investigators to control more fully for mismeasurement, detect evidence of downward rigidity in spikes at zero and the implied positive skewness of wage changes. ${ }^{34}$ While spikes at zero or positive skewness of wage changes are neither necessary nor sufficient signs of downward rigidity, they add to the evidence in support of the grease hypothesis. ${ }^{35}$

Studies of firm-level micro data take another approach to looking for downward nominal rigidities. Transaction-level data on wages paid by firms reflect employers' strategies to avoid downward wage rigidity and are not influenced by worker misreporting. Using such data, Groshen and Schweitzer (1996, 1999) find evidence consistent with downward wage rigidity and determine that the effect of inflation on wage changes is exhausted at inflation levels of about 7 to 9 percent - consistent with the notion that grease benefits are bounded. Using employer data from the Employment Cost Index, Lebow, Saks and Wilson (1999) find additional evidence of downward wage rigidity.

In sum, while each individual micro or macro test may not be fully convincing on its own, taken together the tests provide diverse and fairly consistent evidence that wages are rigid downward.

\footnotetext{
${ }^{34}$ See Akerlof, Dickens and Perry (1996) and Card and Hyslop (1996).

${ }^{35} \mathrm{~A}$ spike is not sufficient because rounding in the data makes occurrences of zero-dollar wage changes common. It is not necessary since truncated workers may be laid off. As far as skewness is concerned, downward rigidities may also affect the upper tail of the distribution if employers limit other workers' salary increases to subsidize constrained workers.
} 


\section{Net Effects of Inflation}

Viewed from the policymaker's perspective, the question is whether inflation at low rates is on net beneficial or detrimental. How low should the monetary authority aim? At zero or something above that? Sand effects are clearly disruptive and rise with inflation, certainly wiping out the net benefits from the grease effects when inflation is high. But how do they compare at low rates? Beyond the impact on the price system's resource allocation mechanism, inflation can interact with the tax system, reducing the steady-state level of output. Furthermore, downward rigidity at the micro level may not translate into higher unemployment when inflation is low, implying that the grease effects themselves could be small. This would occur if the elasticity of demand for labor with respect to these distortions was low because employers honor implicit insurance-style contracts and absorb fluctuations of costs into profits. Finally, inflation may have different effects in different environments.

Thus far (the simulations in Akerlof, Dickens, and Perry [1996] to the contrary), scant evidence of sizable macro effects exists. Indeed, both Card and Hyslop (1996) and Lebow, Saks and Wilson (1999) find little net unemployment impact from downward wage rigidity under normal conditions. Groshen and Schweitzer (1999) estimate that at the point where benefits are maximized, for CPI inflation around $21 / 2$ percent, the net impact of inflation (grease minus sand) is positive but an order magnitude smaller than the gross benefits. They go on to estimate that raising inflation from zero to 4 percent would lower unemployment by less than 1/10 of 1 percentage point. By contrast the net impact of raising inflation from 4 percent to 8 percent would add as much as 3/10 of 1 percentage point to the unemployment rate. Overall, these results suggest that there is little labor market justification for raising real inflation beyond about 1 percent (using an unbiased measure of consumer prices) or raising CPI inflation beyond 2 percent.

However, variation in general productivity growth rates will affect the choice of an optimal inflation target and the resulting monetary policy. The Groshen and 
Schweitzer results are based on the labor productivity growth experience during the sample period under study — that is, the 40 year period from 1957 to 1996. To understand why productivity growth matters for inflation targets, note that productivity growth has effects that are similar to those of inflation - it injects grease and sand into wage setting. Because general productivity growth is even harder to gauge than inflation, it adds confusion (sand) in wage setting. Moreover, because productivity growth raises average nominal wages, it adds grease to the labor market in the same way as inflation does. ${ }^{36}$ Thus, even though productivity growth appears as if it might be unrelated to monetary policy instruments or targets, it affects optimal inflation goals. In particular, as productivity growth strengthens, the amount of grease and sand in the labor market becomes greater, reducing the benefit of adding more inflation. Conversely, as productivity growth declines, the amount of grease and sand in the labor market also falls, increasing the net benefit of inflation.

As a final consideration, policymakers should bear in mind that studies of rigidities and shocks are necessarily specific to a particular economy and time. None of the papers cited provides comparative measures, even though, as we note above, differences in institutions and exposure to shocks may have important implications for policy. In particular, the studies implicitly treat shocks and rigidities as unchanged during the course of the study. While this assumption is entirely appropriate for the short run, it is certainly not true over the long run. Using short-run numbers to derive long-run estimates could bias results. Indeed, of particular policy interest are endogenous responses, such as the posited tendency for downward wage rigidity to relax in the face of persistent low inflation, lowering the grease benefits of raising inflation, and lowering the optimal rate of inflation. Similarly (but with contrasting implications), if low positive inflation rates were maintained with little uncertainty,

\footnotetext{
${ }^{36}$ From the firm's point of view, productivity growth lowers overall lower unit labor costs. This increases overall demand for workers, leading to generally higher wages. However, at any time some workers are facing reduced demand for their skills relative to others. The higher is productivity growth, the wider is the scope for employers of those workers to reduce unit labor costs without lowering their nominal wages.
} 
some sand costs of inflation might dissipate as firms (no longer subject to stop-and-go shocks) were better able to plan for the future and distinguish between real and nominal shocks. Thus, if monetary policy has been the primary source of unpredictable nominal shocks, then to the extent that the policy itself can become more stable, a higher target level of inflation is justified.

A related caveat is that international differences have not yet been studied rigorously. All cited studies of the grease effect rely on US data. Hence, for other economies, the results must be considered suggestive, rather than definitive. By contrast, sand effects have been studied in a wide spectrum of countries, albeit individually rather than comparatively. Ultimately, given their importance for the conduct of sound monetary policy, comparative and longitudinal studies of shocks and rigidities will constitute an important area for further research.

\section{POLICY IMPLICATIONS}

What do we learn from our analysis? We began by noting that economies face both real and nominal shocks and that prices and wages are rigid in response. These rigidities may be asymmetrical (with decreases in prices and wages being more difficult to bring about than increases) or not. The implications for monetary policy are manifold.

First, we have described how theoretical models help guide us in developing measures of trend inflation. These models suggest that trimmed means are more efficient, timely measures of core inflation than the more commonly used indexes that systematically exclude certain components such as food and energy. Second, the research we have surveyed suggests that inflation is very difficult to control accurately, especially at short horizons. This explains why, in designing policy schemes, many central banks and governments have reconsidered the wisdom of adopting narrow inflation-targeting bands. Staying inside the bands may turn out to be an impossible task, damaging 
the credibility of the authorities that put the policy in place.

Finally, we address the question of how to select an optimal inflation target. We note that when prices adjust infrequently, inflation distorts price signals and leads to resource misallocations. But if wages and prices are rigid downward, some amount of inflation facilitates adjustment to real shocks. Recent research has produced measures of the relative size of these costs and benefits in an economy that suggest that inflation targets between zero and 2 percent (bias-adjusted) are optimal.

But there are two important caveats. First, to the extent that labor productivity is increasing on average, there is room to reduce the inflation target. Second, the optimal rate of inflation depends on the mixture of shocks and rigidities to which an economy is subject. Furthermore, a long-run steady rate of low inflation implies fewer nominal shocks and puts pressure on price and wage setters to reduce rigidities. Thus, the optimal rate of inflation may both differ somewhat across countries and evolve over time. 


\section{References}

Akerlof, G. A., Dickens W.T. and Perry, G.L. (1996). "The Macroeconomics of Low Inflation." Brookings Papers on Economic Activity no. 1, pp. 1-74.

Alesina, A., and Summers, L. H. (1993). "Central Bank Independence and Macroeconomic Performance." Journal of Money, Credit, and Banking, vol. 25, no. 2, pp. 151-62.

Álvarez, L. J., and M. de los Llanos Matea. "Underlying Inflation in Spain." In Measures of Underlying Inflation and Their Role in the Conduct of Monetary Policy, proceedings of the workshop of central bank model builders. Bank for International Settlements, June 1999.

Andrés, J. and Hernando I. (1999). "Does Inflation Harm Economic Growth? Evidence from the OECD." In M. S. Feldstein, ed., The Costs and Benefits of Price Stability, Chicago: University of Chicago Press for NBER.

Ball, L. and Cecchetti S.G. (1990). "Inflation and Uncertainty at Short and Long Horizons," Brookings Papers on Economic Activity no. 1, pp. 215-245

Bryan, M. F., and Cecchetti S. G. (1994). "Measuring Core Inflation." In N. G. Mankiw, ed., Monetary Policy, Chicago: University of Chicago Press for NBER.

Bryan, M. F., Cecchetti, S. G. and Wiggins, R.L., II, (1997). "Efficient Inflation Estimation." NBER Working Paper no. 6183.

Card, D. and Hyslop D. (1996). "Does Inflation 'Grease' the Wheels of the Labor Market?" NBER Working Paper no. 5538.

Cecchetti, S. G. (1986). "The Frequency of Price Adjustment: A Study of the Newsstand Prices of Magazines,' Journal of Econometrics, vol. 31, no. 3, pp. 255-74.

, (1995). "Inflation Indicators and Inflation Policy." in B. Bernanke and J. Rotemberg, eds. NBER Macroeconomics Annual. Cambridge, Mass.: MIT Press. 
, (1996) "Practical Issues in Monetary Policy Targeting," Federal Reserve Bank of Cleveland Economic Review, vol. 32, no. 1, pp. 2-15.

— (1998a). "Policy Rules and Targets: Framing the Central Banker's Problem." Federal Reserve Bank of New York Economic Policy Review vol. 4, no. 2, pp. 1-14. , (1998b) "Understanding the Great Depression: Lessons for Current Policy," in M. Wheeler, ed., The Economics of the Great Depression, Kalamazoo, Michigan: W.E. Upjohn Institute for Employment Research, pp. 171-194.

Dow, J. P., Jr. (1994). "Measuring Inflation Using Multiple Price Indexes," Unpublished paper, Department of Economics, University of California at Riverside.

Eckstein, O. (1991). Core Inflation. Englewood Cliffs, N.J.: Prentice-Hall, Inc.

Friedman, M. (1977). Nobel Lecture: "Inflation and Unemployment." Journal of Political Economy, 85, no. 3, pp. 451-72.

Groshen, E. L. and Schweitzer M. (1996). "The Effects of Inflation on Wage Adjustments in Firm-Level Data: Grease or Sand?" Federal Reserve Bank of New York Staff Report no. 9 (revised 1998).

and _ (1997). "Macro- and Microeconomic Consequences of Wage Rigidity." In D. Lewin, D. Mitchell, and M. Zaidi, eds., Handbook of Human Resource Management Greenwich, Conn.: JAI Press.

and _ (1999). "Identifying Inflation's Grease and Sand Effects in the Labor Market." In Martin S. Feldstein, ed. The Costs and Benefits of Price Stability, 273-308. Chicago: University of Chicago Press for NBER.

Haley, J. (1996). "Theoretical Foundations for Sticky Wages." Journal of Economic Surveys vol. 4, no. 2, pp. 115-55. (February):

Huizinga, J. (1993). "Inflation Uncertainty, Relative Price Uncertainty, and Investment in U.S. Manufacturing," Journal of Money, Credit, and Banking vol. 25, no. 3, Part 2, pp. 521-49. 
Lach, S. and D. Tsiddon (1992). "The Behavior of Prices and Inflation: An Empirical Analysis of Disaggregated Price Data." Journal of Political Economy vol. 100, no. 2, pp. 349-89.

Lebow, D. E., Saks, R. E. and Wilson, B. A., (1999). "Downward Nominal Wage Rigidity: Evidence from the Employment Cost Index." Board of Governors of the Federal Reserve System, Finance and Economics Discussion Paper no. 99-32.

Lucas, R. E., Jr., and Rapping, L. A. (1969). "Real Wages, Employment, and the Price Level." Journal of Political Economy, vol. 77, no. 5, pp. 721-54.

Mishkin, F. S. (1999). "International Experience with Monetary Policy Rules." Journal of Monetary Economics, vol. 43, no. 3, pp. 579-606.

Morandé, F. and Schmidt-Hebbel, K. (1999). "The Scope for Inflation Targeting in Emerging Market Economics." Unpublished paper, Central Bank of Chile.

Quah, D. and S. P. Vahey (1995). "Measuring Core Inflation," Economic Journal, vol. 105, no. 432, pp. 1130-44.

Reinsdorf, M. (1994). "New Evidence on the Relation between Inflation and Price Dispersion," American Economic Review, vol. 84, no. 3, pp. 720-31.

Shapiro, M. D., and Wilcox, D. W. (1996). "Bias in the Consumer Price Index." In B. Bernanke and J. Rotemberg, eds. NBER Macroeconomics Annual. Cambridge, Mass.: MIT Press.

Sheshinski, E. and Y. Weiss (1977). "Inflation and Costs of Price Adjustment." Review of Economic Studies, vol. 44, no. 2 pp. 287-303.

Sims, C. A. (1992). "Interpreting the Macroeconomic Time Series Facts: The Effects of Monetary Policy," European Economic Review, vol. 36, no. 4, pp. 975-1000.

Stigler, G. J., and J. K. Kindahl (1970). "The Behavior of Industrial Prices." NBER General Series no. 90. New York: Columbia University Press. 
Tobin, J. (1972). "Inflation and Unemployment." American Economic Review vol. 62 , no. 1 , pp. $1-18$.

Vining, D. R. and T. C. Elwertowski (1976). "The Relationship Between Relative Prices and the General Price Level." American Economic Review, vol. 66, no. 4, pp. 699-708.

Wynne, M. A. (1999). "Core Inflation: A Review of Some Conceptual Issues." In Measures of Underlying Inflation and Their Role in the Conduct of Monetary Pol$i c y$, proceedings of the workshop of central bank model builders. Bank for International Settlements. 